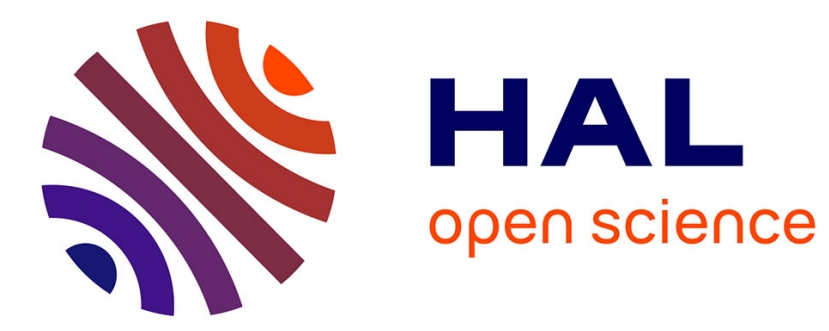

\title{
Jacalin: a new laboratory tool in immunochemistry and cellular immunology.
}

Pierre Aucouturier, Nathalie Pineau, Jean-Christophe Brugier, Edith Mihaesco, Françoise Duarte, Frantisek Skvaril, Jean-Louis Preud'Homme

\section{- To cite this version:}

Pierre Aucouturier, Nathalie Pineau, Jean-Christophe Brugier, Edith Mihaesco, Françoise Duarte, et al.. Jacalin: a new laboratory tool in immunochemistry and cellular immunology.. Journal of Clinical Laboratory Analysis, 1989, 3, pp.244-51. 10.1002/jcla.1860030409 . inserm-01878522

\section{HAL Id: inserm-01878522 https://www.hal.inserm.fr/inserm-01878522}

Submitted on 21 Sep 2018

HAL is a multi-disciplinary open access archive for the deposit and dissemination of scientific research documents, whether they are published or not. The documents may come from teaching and research institutions in France or abroad, or from public or private research centers.
L'archive ouverte pluridisciplinaire $\mathbf{H A L}$, est destinée au dépôt et à la diffusion de documents scientifiques de niveau recherche, publiés ou non, émanant des établissements d'enseignement et de recherche français ou étrangers, des laboratoires publics ou privés. 


\title{
Jacalin: A New Laboratory Tool in Immunochemistry and Cellular Immunology
}

\author{
Pierre Aucouturier, ${ }^{1}$ Nathalie Pineau, ${ }^{1}$ Jean-Christophe Brugier, ${ }^{1}$ Edith Mihaesco, ${ }^{2}$ \\ Françoise Duarte, ${ }^{1}$ Frantisek Skvaril, ${ }^{3}$ and Jean-Louis Preud'homme ${ }^{1}$ \\ 'Laboratory of Immunology and Immunopathology, CNRS URA 1172, University Hospital, Poitiers, France; \\ ${ }^{2}$ Laboratory of Immunochemistry and Immunopathology, INSERM U 108, Hopital Saint Louis, Paris, France; \\ ${ }^{3}$ Institute for Clinical and Experimental Cancer Research, Bern, Switzerland
}

\begin{abstract}
In recent years, a new lectin-jacalin-has raised the interest of immunologists because of its original properties with respect to human immunoglobulins and lymphocytes. Its structure and carbohydrate binding specifity are now well documented, and it can be purified easily from jackfruit seeds by ion exchange or affinity chromatography. The binding and precipitating specificities of jacalin with heavy chains of human immunoglobulins allow its use as a diagnostic (IgA subclass typing) and

removal of lgA from biologic samples and preparations). Other possible applications of jacalin's binding properties also can be envisaged. In addition, the lectin displays a mitogenic activity specific for human CD4 T-lymphocytes; consequently, the proliferative response induced by jacalin appears to represent a new and interesting assay for a functional study of CD4 cells, with obvious applications in primary and acquired, especially AIDS, immune deficiency states.
\end{abstract} preparative tool (purification of $\lg A$ and $\lg D$,

Key words: lectins, human immunoglobulins, human lymphocytes, polyclonal activation

\section{INTRODUCTION}

Lectins are proteins of nonimmune origin and are widely present in vegetables and animals. They were first described as able to precipitate certain serum components (1) and then as agglutinating various cell types, including erythrocytes, leucocytes, tumor cells, bacteriae, and viruses. These various agglutinin activities share the general property of being inhibited by specific monosaccharides or oligosaccharides, which suggests that they are mediated by membrane glycoproteins or glycolipids. After Nowell demonstrated that phytohemagglutinin (PHA) from Phaseolus vulgaris induces blastic transformation of normal lymphocytes (2), the mitogenic property of a variety of lectins was demonstrated; several of these lectins are commonly used today because of their activity on lymphocytes, including PHA, concanavalin A from Canavalia ensiformis, pokeweed mitogen from Phytolacca americana, and many others.

The first demonstration of a potential interest of agglutinin(s) extracted from jackfruit (Artocarpus heterophyllus) seeds in immunology was provided by Bunn-Moreno and CamposNeto (3). Later, immunologists preferred the term jacalin to jackfruit seed agglutinin, which was used by others. Jacalin first received attention because of its mitogenic activity. The first report concluded that crude extract from jackfruit seeds (JCE) can stimulate in vitro human lymphocyte (mostly $\mathrm{T}$ cell) proliferation and immunoglobulin (Ig) production by human B cells (3). Somewhat contradictory results concerning the proliferative response of human lymphocytes to JCE have been published $(4,5)$, but the main interest of jacalin began with demonstration of its reactivity with human IgA by Roque-Barreira and Campos-Neto (6), whose interest was stimulated by the finding of important precipitates in culture media containing jacalin and calf serum. Gel double-diffusion studies showed that, among human serum proteins, only IgA and a few $\alpha 2$-globulins were precipitated by JCE. The well-known difficulties of purifying serum IgA or eliminating IgA from certain preparations (in particular, IgG preparations for therapeutic use) led us to study the properties of jacalin and their possible immunological applications. The present report reviews current knowledge on the chemical nature and binding properties of jacalin and examines its mitogenic activity which, although much less studied, should raise a new interest.

Received December 29, 1988; accepted January 4, 1989.

Address reprint requests to P. Aucouturier, CNRS URA 1172, CHRU La Milétrie, BP 577, F-86021 Poitiers, France.

Abbreviations used: PHA, phytohemagglutinin; JCE, jackfruit seed crude extract: Ig, immunoglobulin; DEAE, diethylaminoethyl; Mr, molecular weight SDS-PAGE, sodium dodecyl sulfate-polyacrylamide gel electrophoresis; PBMC, peripheral blood mononuclear cells. 


\section{CHEMICAL CHARACTERIZATION}

The first immunological studies performed with jacalin were in fact done with JCE obtained by steeping grounded seeds in phosphate-buffered saline for 24 hours $(3,4)$ or with a partially purified preparation $(7,8)$. Discrepant results of certain studies of reactivity with Ig (9) and effects on lymphocytes (see below) of such jacalin preparations pointed out the need for a strict characterization of this lectin. In fact, the first biochemical study of jacalin, performed by Moreira and Ainouz (10), was practically ignored by immunologists. Using jackfruit seeds collected in Brazil, these authors showed the heterogeneity of jacalin's electric charge, which the present authors confirmed using seeds from the Indian Ocean island La Réunion and also from Brazil $(9,11)$. Diethylaminoethyl (DEAE) chromatography of JCE first yields two major fractions (F1 and $\mathrm{F} 2$ ) with comparable capacities of precipitating human IgA; both contain jacalin (defined as IgA-binding molecules made up of two subunits; see below) only. The following fraction (F3) is composed of several proteins migrating in the $\alpha 2$-globulins by standard zone electrophoresis; the last fraction to be eluted (F4) has a yellow-brown color and migrates like serum albumin.

Jacalin, purified by ion exchange or IgA-affinity chromatography, is formed of two types of noncovalently linked glycosylated and unglycosylated subunits with apparent molecular weights (Mr) of 11.25 to $12 \mathrm{kD}$ and 14.7 to $15 \mathrm{kD}$ (10-12), respectively. The amino acid composition of these two subunits is very similar (Table 1). The different native forms of this lectin in fractions $\mathrm{F} 1$ and $\mathrm{F} 2$, termed isolectins by Moreira and Ainouz (10), have the same size as shown by gel filtration under nondissociating conditions ( $\mathrm{Mr}$ about 50 $\mathrm{kD}$ ), but they differ in the proportion of both types of subunits: the unglycosylated/glycosylated subunit ratio is 2.2 to 2.9 in F1 (which contains the bulk of jacalin) and 4.7 to 6.8 in F2 (Fig. 1). The fraction F3 contains a notable proportion of the lectin (as well as F4 to a lower degree) that is easily evidenced by Western blotting using rabbit antijacalin antibodies (Fig. 2). Analysis of jacalin purified by affinity chromatography from F3 showed that the subunit ratio in this fraction is sim-

\section{TABLE 1. Amino Acid Composition of Subunits of Jacalin}

\begin{tabular}{|c|c|c|}
\hline \multirow[b]{2}{*}{ Amino acids } & \multicolumn{2}{|c|}{ Amount from analysis rounded to the nearest integer } \\
\hline & $\begin{array}{l}\text { Nonglycasylated subunit } \\
\text { (mole/mole subunit) }\end{array}$ & $\begin{array}{c}\text { Glycosylated subunit } \\
\text { (mole/mole subunit) }\end{array}$ \\
\hline Lys & 7 & 7 \\
\hline His & 1 & 1 \\
\hline Arg & 2 & 2 \\
\hline $1 / 2 \mathrm{Cys}$ & 0 & 0 \\
\hline Asp & 10 & 11 \\
\hline Thr & 8 & 8 \\
\hline Ser & 10 & 12 \\
\hline Glu & 8 & 10 \\
\hline Pro & 6 & 7 \\
\hline Gly & 16 & 17 \\
\hline Ala & 4 & 6 \\
\hline Val & 9 & 8 \\
\hline $\operatorname{Met}^{\mathrm{a}}$ & 2 & 2 \\
\hline Ile & 7 & 7 \\
\hline Leu & 7 & 8 \\
\hline Tyr & 6 & 6 \\
\hline Phe & 7 & 7 \\
\hline $\operatorname{Trp}$ & $\mathrm{ND}^{\mathrm{b}}$ & ND \\
\hline Total & 110 & 119 \\
\hline
\end{tabular}

Average results from ten analyses. Data from reference 11, with permission of Pergamon Press.

${ }^{a}$ Determined as methionine sulfone.

${ }^{n} \mathrm{ND}$ : not determined

\section{A \\ B

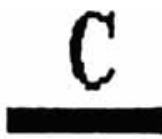 \\ JCE F1 F2 F9 F4 F1 F2 F3 F4 F3 F4}

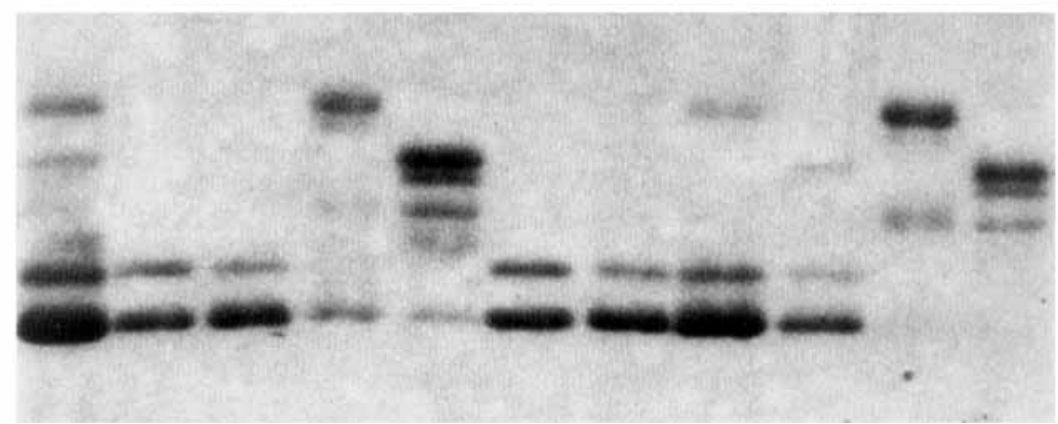

Fig. 1. 15\% SDS-PAGE analysis of JCE and DEAE fractions F1 to F4. A: Whole fractions. B: Their IgA-binding subfractions. C: Non-IgAbinding subfractions from fraction $\mathrm{F} 3$ and $\mathrm{F} 4$ (corresponding subfractions from F1 and F2 contained no detectable material). Coomassie blue staining, unreduced gel. 


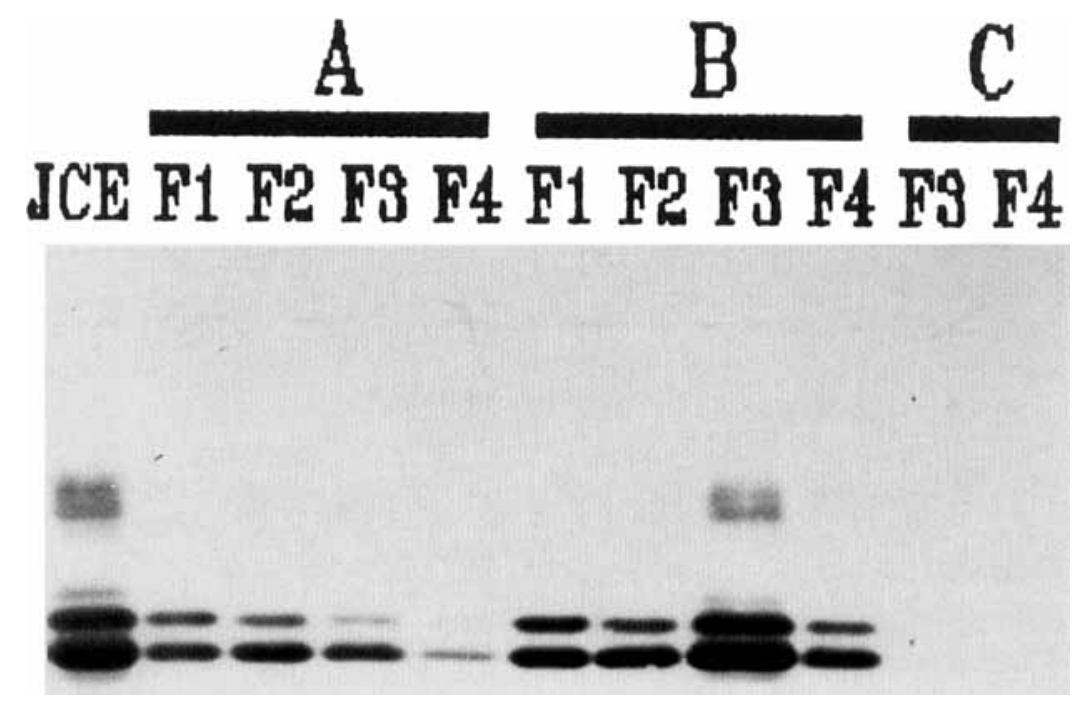

Fig. 2. Same gel as in Figure 1, Western blot with peroxidase-coupled $F\left(a b^{\prime}\right) 2$ fragments of antijacalin antibodies.

ilar to that in $\mathrm{F} 2$; the proportion of unglycosylated subunits in fraction F4 is higher (ratio: 9.5) (13). In JCE as well as in jacalin purified by affinity chromatography from JCE, this ratio is 3 , which first led us to conclude, in view of gel filtration studies of the native molecules, that jacalin was made up of one glycosylated and three unglycosylated subunits (11). In fact, as already mentioned, it presents a striking heterogeneity of electric charge, the reason for which remains unclear, but it could be related to the presence of molecules differing by the proportion of both subunits. When electrophoretic analysis is performed at low $\mathrm{pH}(4.3$ or 4.5$)$, this heterogeneity of charge is no longer observed $(12,14,15)$; this phenomenon probably is due to the dissociation of the subunits, which probably also explains why the lectin loses its reactivity below $\mathrm{pH} 4.5$ (16). In addition, sodium dodecyl sulfate-polyacrylamide gel electrophoresis (SDS-PAGE) of fraction F3, under both reducing and nonreducing conditions, shows molecules of higher $\mathrm{Mr}$ than the subunits (the major one has an apparent $\mathrm{Mr}$ of $26 \mathrm{kD}$ under reducing conditions) that bind IgA and react with antijacalin antibodies (Figs. 1,2). It is also worth mentioning that fraction $\mathrm{F} 4$ contains several non-IgA binding molecules that are unreactive with the antijacalin antibodies. Some of these molecules yield two components of the same size as the jacalin subunits upon reduction.

Although most recent studies confirm the above-mentioned data characterizing jacalin, a few discordances are worth noting. Kumar et al. (14) reported that the lectin is made up of four identical $10.5 \mathrm{kD}$ subunits. We found the $\mathrm{N}$-terminal amino acid to be glycin, whereas Basu et al. (17) found a methionine. These minor discrepancies might be related to apparent differences of reactivity of crude extracts from jackfruit seeds of different geographical origins $(8,18)$ (see below).

\section{CARBOHYDRATE SPECIFICITY}

Jacalin is known to be an $\alpha$ D-galactoside-spscific lectin (14). The use of p-nitrophenyl- $\alpha \mathrm{D}$-galactoside and 4-methylumbelliferone- $\alpha$ D-galactoside allowed evaluation by equilibrium dialysis and fluorescence quenching of its association constants with these ligands ( $\mathrm{Ka}=1.4 \times 10^{5}$ and $2.1 \times 10^{5}$ $\mathrm{M}^{-1}$ at $25^{\circ} \mathrm{C}$ ), which led to the conclusion that there are only two binding sites per molecule (19). This conclusion, although based on the hypothesis of a homogeneous and homotetrameric structure of the lectin (14), which has not as yet been confirmed by others (see above), is worth noting because it would represent the first case of a lectin whose binding activity requires the quaternary association of subunits. Appukuttan and Basu (20) also demonstrated the importance of lysyl and tyrosyl residues to binding activity. The involvement of tyrosyl explains at least in part the intrinsic fluorescence changes of the lectin after ligand binding. This property allowed demonstration that $\mathrm{C} 1, \mathrm{C} 2, \mathrm{C} 4$, and $\mathrm{C} 6$ galactose hydroxyl groups are determinant (21); inversion of $\mathrm{C} 4$ hydroxyl in the glucose molecule and absence of $\mathrm{C} 6$ hydroxyl in fucose thus explain the nonreactivity of these sugars. On the other hand, the $\alpha$-anomer of galactose binds more strongly than does the $\beta$-anomer.

Thermodynamic studies of jacalin binding to several monosaccharides and disaccharides showed the strongest ligand by far to be DGal $\beta 1 \rightarrow 3$ DGalNAc (22). In agreement with this, we independently found that $\mathrm{N}$-acetylgalactosamine and galactose are the two monosaccharides that are the strongest inhibitors of binding of jacalin to IgA coats, with lactose showing a much lower but significant inhibition capacity (11) (Fig. 3 ). This latter result does not confirm a previous work (16) in which lactose was found to be unreactive, but it agrees 


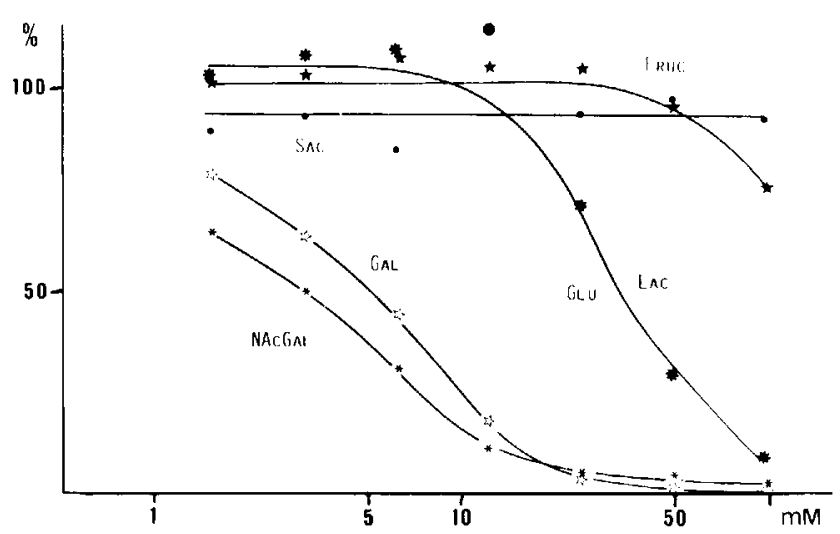

Fig. 3. Competitive ELISA: inhibition of binding of jacalin-peroxidase to IgAl coats by increasing concentrations of $\mathrm{N}$-acetylgalactosamine (NAcGal), galactose (Gal), glucose (Glu), lactose (Lac), saccharose (Sac), and fructose (Fruc).

with similar findings by other investigators (22). The $\beta 1 \rightarrow 4$ linked glucose and $\mathrm{N}$-acetylglucosamine $\mathrm{C} 3$ hydroxyl groups present in lactose and $\mathrm{N}$-acetyllactosamin, respectively, and $\mathrm{N}$-acetylglucosamin $\mathrm{C} 4$ hydroxyl in Gal $\beta 1 \rightarrow 3 \mathrm{GlcNAc}$ explain the much lower affinity of these ligands. Gal $\beta 1 \rightarrow 3 \mathrm{GalNAc}$ residues are o-glycosidically linked to serine or threonine in numerous animal proteins. Consequently, jacalin can precipitate a variety of proteins, such as ant egg glycoprotein and human glycophorin (23). Also, a precipitation reaction was observed between jacalin and certain batches of bovine serum albumin, suggesting that this reaction was due to contaminants. Finally, jacalin agglutinates human erythrocytes of all blood groups $(10,14)$; it binds to the surface of all human peripheral blood cells, as shown by direct immunofluorescence with fluorescein-conjugated jacalin (unpublished results).

\section{REACTIVITY WITH IMMUNOGLOBULINS}

\section{Precipitating Assays}

In most studies, including the present one, of the reactivity of jacalin with human Ig, only $\operatorname{IgA} 1$ and $\operatorname{IgD}$ were found to be precipitated by jacalin $(7,9,11,24)$; this specificity, which was also clear when Western blot methods were used (11), is well explained by the presence of o-glycosidically linked $\mathrm{Gal} \beta 1 \rightarrow 3 \mathrm{GalNAc}$ (ocassionally sialylated) residues on the hinge region of $\alpha 1$ and $\delta$ chains $(25,26)$ but not on other human Ig heavy chains. Using proteolytic fragments yielded by Neisseria gonorrhea and Streptococcus sanguis proteases, Skea et al. (27) confirmed that jacalin reacts with the hinge region of IgA1. In precipitation assays, the subclass specificity is clear, as all 76 monoclonal $\operatorname{IgA} 1$ and none of the seven IgA2 [5 $\operatorname{IgA} 2 \mathrm{~m}(1)$ and two $\operatorname{IgA} 2 \mathrm{~m}(2)]$ tested were precipitated by jacalin. This provides a simple and reliable method for typing myeloma $\operatorname{IgA}(28)$. $\operatorname{IgD}$ reactivity is more controversial; whereas all 13 myeloma IgD assayed in our laboratory and six more tested by others (24) were precipitated by jacalin, some authors found this isotype to react only after neuraminidase treatment (15) or not at all (7). It is worth recalling that $\mathrm{IgD}$ is very prone to proteolysis and that its degradation quickly impairs its jacalin reactivity, even while it is still precipitated by anti- $\delta$ antisera (11), which might explain these inconsistencies. The lectin does not precipitate $\operatorname{IgG}, \operatorname{IgM}$, and $\operatorname{IgE}$ according to most studies.

In contrast, although they observed a similar specificity with JCE from seeds collected in the Philippines, Kondoh et al. (8) found positive reactions by gel double-diffusion between a half-purified jackfruit seed preparation from Okinawa and $\operatorname{IgM}, \operatorname{IgA} 2 \mathrm{~m}(2)$, and $\operatorname{IgE}$ (in addition to precipitation with $\lg \mathrm{A} 1$ and $\operatorname{IgD}$ ); later on, these same authors reported the reactivity of $\operatorname{IgA} 2$ of both allotypes, $\operatorname{IgM}, \operatorname{IgE}$, and even aggregated IgG with a preparation from a peculiar batch of jackfruit seeds that were "rounder and thicker in shape" than others (18). It was suggested that these differences might reflect variations of the properties of jacalin according to the geographic origin of the jackfruit seeds. Despite the great potential interest of these results, they probably should be viewed cautiously because of some methodological points, which have been previously discussed (9). Jacalin from seeds originating from three distinct geographic areas-Brazil, La Reunion, and the Philippines-were used in the present study, and no differences were found; however, this does not rule out the possibility of geographical and even species-related differences in jacalin preparations. There are many species of Artocarpus, each with a number of vernacular names and scientific synonyms. This results in some confusion in immunologic papers; for example, $A$. integrifolia and $A$. integra sometimes were considered the same, sometimes as different (29) species. It is, however, clear from botanical publications $(30-33)$ that the jack ( $A$. heterophyllus, most common synonyms $A$. integrifolia and $A$. integra), which originates from India and has spread throughout the tropics since prehistory has wellknown botanical characteristics that allow an easy distinction with other trees of the same genus (also cultivated for their edible fruits), such as the breadfruit ( $A$. altilis) and the champedak ( $A$. integer). However, there is a great variability within the single species $A$. heterophyllus. Perhaps more importantly, natural or artificial hybridization between $A$. heterophyllus and A. integer is known to occur, for example, in the Philippines.

\section{Nonprecipitating Assays}

Analysis of Ig-jacalin interactions by nonprecipitating assays is a matter of controversy, especially concerning $\operatorname{IgA} 2$. This is a critical issue, as jacalin, which can easily be coupled to Sepharose beads by the cyanogen bromide method, is undoubtedly a very efficient tool to purify $\operatorname{IgA}$ and $\operatorname{IgD}$ or to remove IgA from therapeutic IgG preparations, for instance (11). Jacalin thus makes it much easier to obtain pure $\operatorname{IgA} 1$ or $\operatorname{IgA} 2$ from myeloma sera. IgA2 was not found in material purified 
from a few sera by jacalin-affinity chromatography $(24,27)$, but it was evaluated in one of these studies (27) by a rather insensitive assay (protease resistance). In another study (15), inhibition by $\operatorname{IgA} 2$ of the agglutination by jacalin of latex beads coupled to IgAI was assumed to reflect contamination by IgA1. In contrast, we found a reactivity of $\operatorname{IgA} 2$ with jacalin that was much weaker than that of $\operatorname{IgA} 1$ but significant nonetheless (11), and attempts to separate IgA subclasses by jacalinagarose affinity chromatography were not always completely successful. Thus, Gregory et al. (34) obtained pure IgA2 by passing colostrum on a jacalin column, but the eluted IgA 1 were contaminated by $8 \% \operatorname{IgA} 2$. On the other hand, the procedure described by Kondoh et al. (8) to purify secretory $\operatorname{IgA} I$ and $\operatorname{IgA} 2$ does not exclude, in our opinion (9), the possibility of a contamination of the $\operatorname{IgA} 1$ fraction by $\operatorname{IgA} 2$ because of the lack of sensitivity of control experiments. We recently confirmed that $\operatorname{IgA} 2$ of both allotypes binds to jacalin agarose. However, monoclonal IgA2 can hardly be purified from myeloma sera in this way, because jacalin-binding proteins, although they contain fair amounts of $\operatorname{IgA2}$, are considerably enriched in residual IgA1 $(11,35)$ (Fig. 4). Indeed, inhibition experiments of the binding of jacalin to IgAl-coated polystyrene by human $\operatorname{Ig}$ of each isotype show that $\operatorname{IgD}$ and IgA 1 display a much higher apparent affinity than does $\operatorname{IgA} 2$ (35) (Fig. 5). It is worth noting that, in our hands, IgA2 shows a very similar inhibition of binding of $\operatorname{IgA} 1$ to jacalins from Brazil, La Réunion, and the Philippines. This affinity difference allows the removal of $\operatorname{IgA} 1$ from $\operatorname{IgA} 2$ preparations. In unpublished experiments, four IgA2 myeloma preparations and a normal serum pool were incubated for 1 hour at $25^{\circ} \mathrm{C}$ and for 2 hours at $4^{\circ} \mathrm{C}$, with increasing amounts of jacalin or JCE coupled to cyanogen bromide-activated Sepharose; $\operatorname{IgA} 1$ and IgA2 levels then were measured by radial immunodiffusion. These experiments allowed estimation of the amount of immobilized jacalin required to eliminate completely $1 \mathrm{mg}$ of $\operatorname{IgA} 1$, with a minimum loss of IgA2, of $2 \mathrm{mg}$. On the other hand, a consequence of the reactivity of jacalin with $\operatorname{IgA}$ belonging to both subclasses is its possible use to remove readily and completely IgA from IgG preparations for therapeutic use (11), which may be critical when dealing with patients presenting with anti-IgA antibodies or known to be prone to the development of such antibodies, as in combined IgA and IgG2 deficiency.

Conversely, IgA I-affinity chromatography provides an easy way to purify the lectin from JCE $(11-13,15,27,36)$. Because of its reactivity with galactomannans (16), insolubilized guar gum can also be used to prepare jacalin, which is possibly a simpler method (37). However, it should be pointed out that preparative methods based on protein charge, such as DEAE chromatography or zone electrophoresis on Pevikon C870, yield pure jacalin (according to SDS-PAGE with silver staining and demonstration of a single $\mathrm{N}$-terminal amino acid) with a remarkable yield (11).

Jacalin does not bind mouse, rat, pig, goat, horse, cow, or

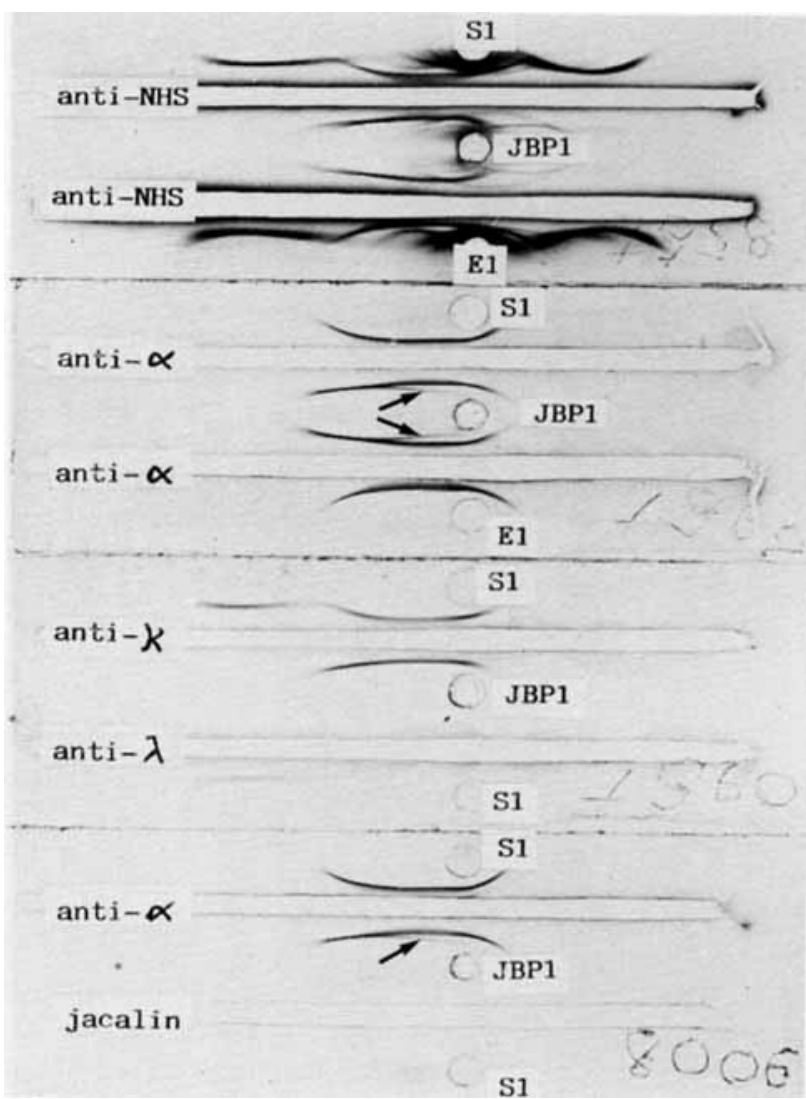

Fig. 4. Immunoelectrophoretic analysis of jacalin-binding proteins (JBP1) and effluent (El) obtained by affinity chromatography of an ammonium sulfate precipitate from an $\operatorname{IgA} 2 \mathrm{~m}(\mathrm{l}) \mathrm{x}$ myeloma serum (SI). Anti-NHS: polyvalent antinormal human serum antiserum. Note (1) that, although the bulk of the IgA2 is in the effluent, it is also present in JBP, and (2) the spur of polyclonal IgA1 over $\operatorname{lgA} 2$ (arrow). Data from reference 35 , with permission of Elsevier.

$\operatorname{dog} \operatorname{Ig}$ A $(38,39)$. We are not aware of any data concerning its reactivity with rabbit serum Ig; preliminary results from our laboratory might indicate that jacalin could bind rabbit IgG and their pepsin $F\left(a b^{\prime}\right) 2$ fragments (unpublished), which should be related to a peculiar glycosylation of the hinge region of some of these molecules (40). Finally, rabbit secretory IgA binds jacalin (38); this property might be useful for the study of the glycosylation of this Ig class, which displays an important isotypic diversity in this species (41).

\section{MITOGENIC PROPERTIES}

The finding that JCE is mitogenic for human peripheral blood mononuclear cells (PMBC) $(3,4)$ led us to investigate the modalities of this activity. All four DEAE fractions (see above) display such an activity; however, as demonstrated by adsorption on human IgA1, reactivity with antijacalin antibodies on Western blots and study of the inhibition of lym- 
(A)

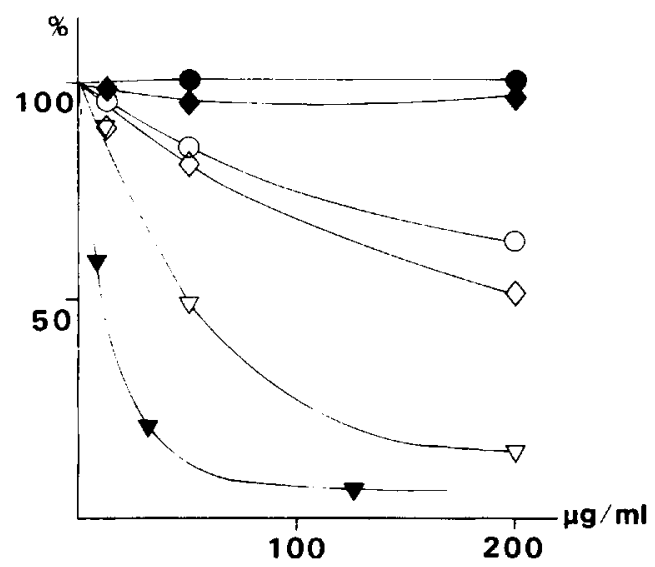

Fig. 5. Inhibition of binding to $\operatorname{IgA} 1$ coats of jacalin $(\mathbf{A})$ and of the anti$\alpha 1$ monoclonal antibody M4D8 (B) by purified $\operatorname{IgA} 1 \times(\nabla), \operatorname{IgA} 2 \mathrm{~m}(1) \times(O)$,

phocyte stimulation by $\operatorname{IgA} 1$, the activity of fractions F1, F2, and $\mathrm{F} 4$ is entirely due to jacalin, whereas $\mathrm{F} 3$ also contains one or more other mitogenic molecule(s) (13).

When incubated with peripheral blood mononuclear cells (PBMC) at the optimum concentration of $200 \mu \mathrm{g} / \mathrm{ml}$, jacalin leads to a maximum ${ }^{3} \mathrm{H}$-thymidine incorportion on day 3 of culture. Although it can bind virtually all blood cells, in our hands, only $\mathrm{T}$ lymphocytes were stimulated. In addition, jacalin fails to induce any plasma cell differentiation of blood B cells, as shown by cytoplasmic immunofluorescence with anti-Ig conjugates. This observation does not confirm the first study (3), but it is in agreement with more recent data (4). We have studied the mitogenic properties of jacalin with respect to T-cell subpopulations (13). Indirect immunofluorescence studies of membrane antigens with monoclonal antibodies showed that after 7 days of culture of PBMC with jacalin, CD4-bearing $T$ cells accounted for most viable cells. Monocyte depletion of PBMC abolishes almost completely the mitogenic activity of jacalin. Similarly, isolated CD4 and CD8 T cells fail to respond to jacalin. The proliferative response of purified CD4-positive cells (and not that of CD8 cells) is recovered by the addition of syngeneic (but not allogeneic) monocytes or partially by recombinant interleukin 1 (Fig. 6). Monocytes primed by 24-hour culture with jacalin and then washed are unable to stimulate lymphocytes. In fact, short incubations ( $1-18$ hours) of unseparated PBMC with jacalin followed by washing and further culture for up to 4 days fail to induce any proliferative response.

A recently published study by Gattass et al. (5) reported that jacalin could inhibit OKT8 antibody binding to PBMC. However, cocapping experiments using fluorescein-conjugated jacalin and anti-CD1, CD2, CD3, CD4, CD8, and CD38 antibodies performed in our laboratory did not show any significant binding of the lectin to these antigens. It is
(B)

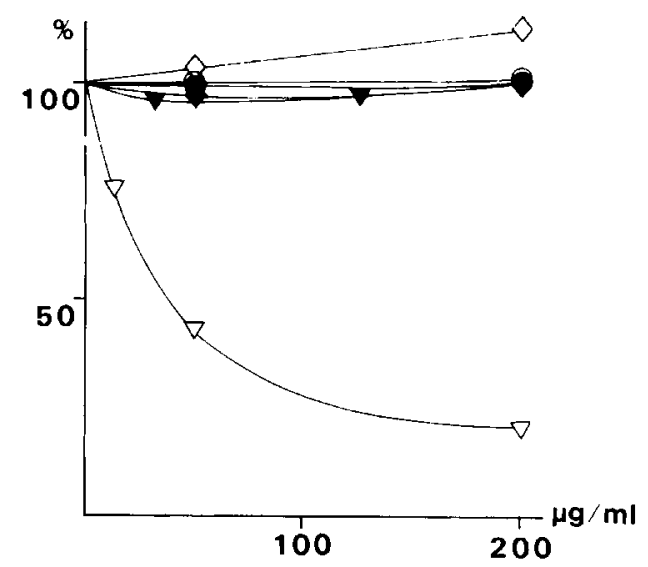

$\operatorname{IgA} 2 \mathrm{~m}(2) \mathrm{x}(\diamond), \operatorname{IgD} \lambda(\boldsymbol{\nabla}), \operatorname{IgG} 3 \times(\bigcirc)$, and $\operatorname{IgMx}(\diamond)$. Percentages of optical densities recorded in the absence of inhibitor.

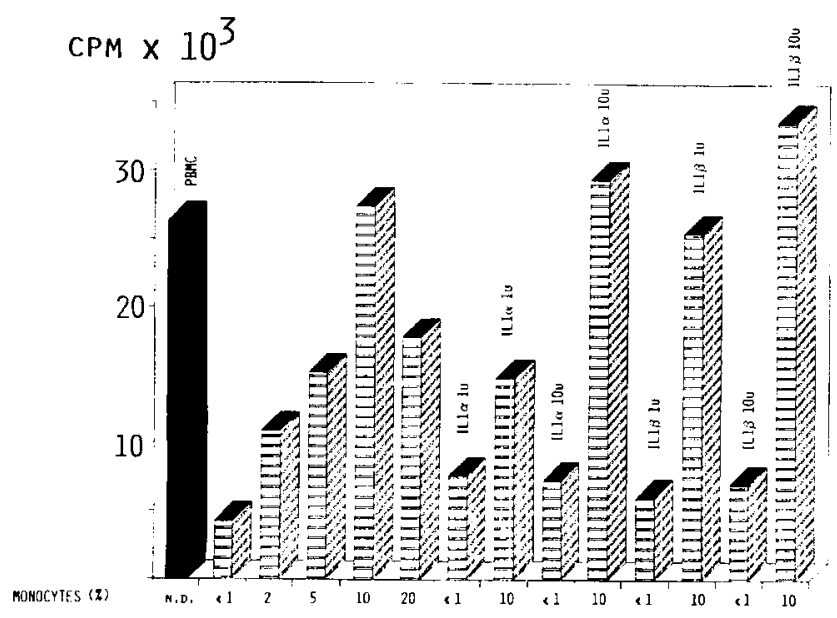

Fig. 6. Proliferative response of normal human PBMC and purified CD4 $\mathrm{T}$ cells in the presence of increasing percentages of monocytes and of ILI (data from eight experiments).

worth noting that JCE induces the production of $\gamma$-interferon by human $T$ cells (42).

\section{PERSPECTIVES}

As discussed above, the structure and properties of jacalin are already well documented, and there is every reason to believe that its immunological applications will be increasingly utilized. It is worth mentioning that other lectins can react with Ig. Among them, PHA displays an interesting isotypic specificity, as it precipitates only $\operatorname{IgA} 2$, pentameric $\operatorname{IgM}$, and some polymeric IgAl (43). Therefore, together with jacalin, PHA may be used to characterize monoclonal Ig in lymphoproliferative disorders $(44,45)$. Lymphocyte polyclonal activation and serum protein precipitation activities of PHA are due to different entities $(46,47)$. On the contrary, jacalin 
is a well-defined molecule and both its effect on lymphocytes and its reactivity with Ig are related to the same wellcharacterized lectinic property. Although, as already discussed, jacalin allows the distinguishing of human IgA subclasses by gel precipitation tests, it must be emphasized again that it also binds $\operatorname{IgA} 2$ of both allotypes in nonprecipitating assays. Therefore, its use for separating IgA subclasses is not in itself a purity criterion, and technical conditions must be adapted to take advantage of the difference in the affinity of $\operatorname{IgAl}$ and IgA2.

PHA and jacalin have also some homologies with respect to their mitogenic properties, as they both stimulate $T$ cells. However, although PHA induces the proliferation of all T-cell subsets (48), jacalin acts only on CD4-positive cells. In addition, the presence of monocytes is required for jacalin stimulation, whereas PHA can recruit other accessory cells, including lymphocytes (49). The CD4 cell specificity of jacalin makes it a potential tool for a functional study of these cells, especially in immunodeficiency states in which this lymphocyte subset is impaired. Our preliminary results in HIV-infected patients (50) showed that the in vitro response to jacalin is indeed depressed, with a significant correlation with the number of blood CD4 lymphocytes. In certain cases, response to other mitogens such as PHA remains normal, whereas jacalininduced proliferation is strongly reduced. The question remains open as to whether this abnormality is due to monocyte or lymphocyte functional defect and whether it has any prognostic significance.

In addition to these major applications, the use of jacalin has been considered for preparing certain polysaccharides (51) or glycoproteins. Thus, Hiemstra et al. (36) reported that complement $\mathrm{C} 1$ inactivator can be purified by jacalin affinity chromatography without losing its activity; moreover, these authors demonstrated that jacalin activates the classical pathway of complement by blocking $\mathrm{Cl}$ inactivator. The use of jacalin thus may be envisaged in the exploration of any biological system in which it could interfere with regulatory glycoproteins.

\section{ACKNOWLEDGMENTS}

This work was supported in part by INSERM-CNRS Programmes National de Recherche sur le SIDA, and by Fondation pour la Recherche Médicale.

The authors thank Professors J. Barrau (Museum National d'Histoire Naturelle, Paris) and J.L. Pousset (Poitiers) for helpfull discussions and Dr. P. Goube de Laforest (Poitiers) for his help in the study.

\section{REFERENCES}

1. Stillmark H: Arheiten des Pharmakologischen Institutes zu Dorpat. R. Kobert, ed. Enke, Stuttgart, 1889, p 57.

2. Nowell PC: PHA: An initiator of mitosis in cultures of normal human lymphocytes. Cancer Res 20:462-465, 1960.
3. Bunn-Moreno MM, Campos-Neto A: Lectin(s) extracted from seeds of Artocarpus integrifolia (jackfruit): Potent and selective stimulator(s) of distinct human T and B cell functions. J Immunol 127:427-429, 1981.

4. Saxon A. Tsui F, Martinez-Maza O: Jacalin, an IgA-binding lectin, inhibits differentiation of human $B$ cells by both a direct effect and by activating T-suppressor cells. Cell Immunol 104:134-141, 1987.

5. Gattass CR, Ghobrial I, Bunn-Moreno MM: Specific inhibition of OKT8 binding to peripheral blood mononuclear cells by jacalin. Immunol Lett 17:133-138, 1988 .

6. Roque-Barreira MC, Campos-Neto A: Jacalin: an IgA-binding lectin. $J$ Immunol 134:1740-1743, 1985.

7. Kondoh H, Kobayashi K, Hagiwara K, Kajii T: Jacalin, a jackfruit lectin, precipitates IgA1 but not IgA2 subclass on gel diffusion reaction. $J$ Immunol Methods 88:171-173, 1986.

8. Kondoh H, Kobayashi K, Hagiwara K: A simple procedure for the isolation of human secretory $\operatorname{IgA}$ of $\operatorname{IgA} 1$ and $\operatorname{IgA} 2$ subclass by a jackfruit lectin, jacalin, affinity chromatography. Mol Immunol 24:1219-1222, 1987.

9. Aucouturier P, Pineau N, Preud'homme JL: A simple procedure for the isolation of human secretory $\operatorname{IgA}$ of $\operatorname{IgA} 1$ and $\operatorname{IgA} 2$ subclass by a jackfruit lectin, jacalin, affinity chromatography. Mol Immunol 25:321-322, 1988.

10. Moreira RA, Ainouz IL: Lectins from seeds of Jack Fruit (Artocarpus integrifolia $L$.). Isolation and purification of two isolectins from the albumin fraction. Biol Plant 23:186-192, 1981.

11. Aucouturier P, Mihaesco E, Mihaesco C, Preud'homme JL: Characterization of jacalin, the human $\operatorname{IgA}$ and $\operatorname{IgD}$ binding lectin from jackfruit. Mol Immunol 24:503-511, 1987.

12. Roque-Barreira MC, Praz F, Halbwachs-Mecarelli L, Greene LJ, Campos-Neto A: IgA-affinity purification and characterization of the lectin jacalin. Braz J Med Biol Res 19:149-157, 1986.

13. Pineau N, Aucouturier P, Brugier JC, Preud'homme JL: Jacalin: A lectin mitogenic for human CD4 $\mathrm{T}$ lymphocytes. (Submitted).

14. Kumar SG, Appukuttan PS, Basu D: $\alpha$-D-Galactose-specific lectin from jackfruit (Artocarpus integra) seed. J Biosci 4:257-261, 1982.

15. Hagiwara K, Collet-Cassart D, Kobayashi K, Vaerman JP: Jacalin: isolation, characterization, and influence of various factors on its interaction with human $\operatorname{IgA} 1$, as assessed by precipitation and latex agglutination. Mol Immunol 25:69-83, 1988.

16. Appukuttan PS, Kumar GS, Basu D: Polysaccharide precipitation as a model to study sugar binding by lectins: Jack Fruit seed lectin interaction with galactomannan. Indian J Biochem Biophys 21:353-356, 1984.

17. Basu D, Delucas L, Parks EH, Suddath FL: Preliminary crystallographic study of the $\alpha-D$-Galactose-specific lectin from Jack Fruit (Artocarpus integra) seeds. J Mol Biol 201:661-662, 1988.

18. Kondoh $\mathrm{H}$, Kobayashi $\mathrm{K}$ : Elimination of undesirable immunoglobin contaminants including aggregated $\operatorname{IgG}$ from $\gamma$-globulin preparations by jackfruit lectin affinity chromatography. Clin Chim Acta 174:15-24, 1988.

19. Appukuttan PS, Basu D: Four identical subunits in jack fruit seed agglutinin offer only two saccharide binding sites. FEBS Lett 180:331-334, 1985.

20. Appukuttan PS, Basu D: Binding site amino acid residues of jack fruit (Artocarpus integrifolia) seed lectin: chemical modification and protein difference spectral studies. J Biosci 7:7-14, 1985.

21. Sastry MVK, Surolia A: Intrinsic fluorescence studies of saccharide binding to Artocarpus integrifolia lectin. Biosci Rep 6:853-860, 1986.

22. Sastry MVK, Banarjee P, Patanjali SR, Swamy MJ, Swarnalatha GV, Surolia A: Analysis of saccharide binding to Artocarpus integrifolia lecin reveals specific recognition of T-antigen ( $\beta$ DGal $(1 \rightarrow 3)$ DGalNAc). J Biol Chem 261:11726-11733, 1986.

23. Chatterjee BP, Uhlenbruck G: Occurence of an anti-Thomsen-Friedenreich like lectin in jackfruit seeds reacting with a receptor in ant egg glycoprotein. Experientia 38:1225-1226, 1982. 
24. Zehr BD, Litwin SD: Human IgD and IgAl compete for D-Galactoserelated binding sites on the lectin jacalin. Scand J Immunol 26:229-236, 1987.

25. Baenziger J, Kornfeld S: Structure of the carbohydrate units of IgA I immunoglobulin. II. Structure of the o-glycosidically linked oligosaccharide units. I Biol Chem 249:7270-7281, 1974.

26. Mellis S, Baenziger J: Structures of the o-glycosidically linked oligosaccharides of human lgD. J Biol Chem 258:11557-11563, 1983.

27. Skea DL, Christopoulous P, Plaut AG, Underdown BJ: Studies on the specificity of the IgA-binding lectin, jacalin. Mol Immunol 25:1-6, 1988.

28. Aucouturier P, Preud'homme JL: Subclass distribution of human myeloma proteins as determined with monoclonal antibodies. Immunol Lett 16:55-77, 1987.

29. Kobayashi K, Kondoh H, Hagiwara K, Vaerman JP: Jacalin: chaos in its immunoglobulin-binding specificity. Mol Immunol 25:1037-1038, 1988.

30. Quisumbing E: Medicinal plants of the Philippines. Genus Artocarpus Forster. Republic of the Philippines Department of Agriculture Natural Resources Technical Bull 16:226 230, 1951.

31. Jarrett FM: Studies in Artocarpus and allied genera, HI. A revision of Artocarpus subgenus Artocarpus. J Arnold Arboretum 11:327-349, 1959.

32. Purseglove IW: Tropical crops. Dicotyledons 2. Longmans, London, 1968.

33. Barrau J: Breadfruit and relatives. Artocarpus spp. (Moraceac). In Evolution of Crop Plants, N.W. Simmons, ed., Longman, London, 1976, p 201-202.

34. Gregory RL, Rundegren J, Arnold RR: Separation of human $\operatorname{lgA} 1$ and IgA2 using jacalin-agarose chromatography. I Immunol Methods 99: 101-106, 1987.

35. Aucouturier P, Duarte F, Mihaesco E, Pineau N, Preud'homme JL: Jacalin, the human $\operatorname{IgA} 1$ and $\operatorname{IgD}$ precipitating lectin, also binds $\operatorname{IgA} 2$ of both allotypes. J Immunol Methods 113:185-191, 1988.

36. Hiemstra PS, Garter A, Stuurman ME, Van Es LA, Daha MR: The IgA-binding lectin jacalin induces complement activation by inhibitation of Cl-inactivator function. Scand J/ /mmunol 26:111-117, 1987.

37. Appukuttan PS, Surolia A, Bachhawat BK: Isolation of two galactosebinding proteins from Ricinus communis by affinity chromatography. Indian J Biochem Biophys 14:382-384, 1977.

38. Skea DL, Underdown BJ: Species and subclass specificity of the IgAbinding lectin jacalin. 6th International Congress of Immunology, Toronto, Canada, 1986, Abstract 1.43.13.
39. Wilkinson R, Neville S: Jacalin: Its binding reactivity with immunoglobulin A from various mammalian species. Vet Immunol Immunopathol 18:195-198, 1988

40. Hinrichs WA, Smyth DG: Studies on the asymmetrically attached oligosaccharide on rabbit immunoglobulin G. Immunology 18:759-767, 1970.

41. Knight KL, Bumett RC, McNicholas JM: Organization and polymorphism of rabbit immunoglobulin heavy chain genes. $J$ Immunol 134:1245-1250, 1985.

42. Crane I, Leung H, Barwick S, Parti S, Meager A: The preparation of interferon gamma-producing $\mathrm{T}$-cell hybridomas from jacalin-stimulated T lymphocytes and the SH9 T-cell line. Immunology 53:855-859, 1984.

43. Spengler GA, Weber RM: Application of PHA in electrophoretic differentiation of humoral immunoglobulins. In Electrophoresis ' 79 Advanced Methods, Biochemical and Clinical applications, B.J. Radola, ed., W. de Gruyter and Co., Berlin, 1979, p 761-764.

44. Spengler GA, Weber RM: Precipitin reactions with PHA-A new tool in diagnostic differentiation of immunoglobulins. In Protides of Biological Fluids, H Peeters, ed., 27, Pergamon press, Oxford, 1979, p 615-618.

45. Spengler GA, Weber RM: PHA selection electrophoresis-A screening method for monomeric IgM. J Immunol Meth 32:71-84, 1980.

46. Weber T, Nordman CT, Gräsbeck R: Separation of lymphocyte stimulating and agglutinating activities in phytohemagglutinin (PHA) from Phaseolus vulgaris. Scand J Haematol 4:77--80, 1967.

47. Miller JB, Noyes C, Heinrikson R, Kingdon HS, Yachnin S: Phytohemagglutinin mitogenic proteins. Structural evidence for a family of isomitogenic proteins. J Exp Med 138:939-951, 1973.

48. Moretta A, Pantaleo G, Maggi E, Mingari MC: Recent advances in the phenotypic and functional analysis of human T lymphocytes. Semin Hematol 21:257-270, 1984.

49. Oudrhiri N, Farcet JP, Gourdin MF, Divine M, Bouguet J, Fradelizi D, Reyes F: Mechanism of accessory cell requirement in inducing IL2 responsiveness by human $\mathrm{T} 4$ lymphocytes that generate colonies under PHA stimulation. J Immunol 135:1813-1818, 1985.

50. Pineau N, Brugier JC, Aucouturier P, Breux JP, Preud'homme JL: Jacalin: A new tool to evaluate lymphocyte reactivity in HIV-infected patients. IV International Conference on AIDS, Stockholm, Abstract 2049, p 176 , 1988.

51. Chowdhury S, Ray S, Chattcrjee BP: Single step purification of polysaccharides using immobilized jackfruit lectin as affinity adsorbent. Glycoconjugate J 5:27-34, 1988. 